\title{
Detection of Clavibacter michiganensis subsp. sepedonicus in Potato Tubers by BIO-PCR and an Automated Real-Time Fluorescence Detection System
}

\author{
N. W. Schaad, ARS-USDA Foreign Disease-Weed Science Research Unit, Frederick, MD 21702; Y. Berthier- \\ Schaad, Perkin Elmer, Foster City, CA; A. Sechler, ARS-USDA; and D. Knorr, Perkin Elmer
}

\begin{abstract}
Schaad, N. W., Berthier-Schaad, Y., Sechler, A., and Knorr, D. 1999. Detection of Clavibacter michiganensis subsp. sepedonicus in potato tubers by BIO-PCR and an automated real-time fluorescence detection system. Plant Dis. 83:1095-1100.

Ring rot of potato, caused by Clavibacter michiganensis subsp. sepedonicus, is one of the most regulated diseases of potatoes world wide. The organism is often difficult to detect in symptomless tubers because of low populations and slow competitive growth on available media. Polymerase chain reaction (PCR) primers and a fluorescent probe for use in the Perkin Elmer 7700 automated real time PCR detection system (TaqMan) were designed from a C. michiganensis subsp. sepedonicus-specific genomic DNA fragment for development of a BIO-PCR assay for $C$. michiganensis subsp. sepedonicus in potato tubers. Results of screening the primers with strains of $C$. michiganensis subsp. sepedonicus and other bacteria showed the primers to be specific. A total of 30 naturally infected ring rot suspect tubers were sampled by the core extract, shaker incubation procedure and assayed by (i) plating aliquots onto agar media, (ii) classical PCR, and (iii) BIO-PCR. In all, 4 tubers were positive by agar plating and pathogenicity tests, 8 by classical TaqMan PCR, and 26 by TaqMan BIO-PCR. We conclude that BIO-PCR combined with the TaqMan automated closed detection system is a rapid, reliable method of assaying large numbers of potato tuber extracts for $C$. michiganensis subsp. sepedonicus. Furthermore, for a large central laboratory running large numbers of PCR assays, the high-throughput TaqMan system can reduce costs per sample over the more labor-intensive classical PCR.
\end{abstract}

Ring rot of potato is one of the most regulated diseases of potatoes world wide (7). The only reliable control for the disease is avoidance and clean seed materials. Most potato-producing countries in North America and Europe have a strict zerotolerance quarantine on the pathogen, Clavibacter michiganensis subsp. sepedonicus (C. michiganensis subsp. sepedonicus; 1,7,9). The organism has been difficult to detect in soil or infected tubers because $C$. michiganensis subsp. sepedonicus grows very slowly, is present in low numbers, and is often overgrown on agar media by saprophytes (9). Colonies of most strains are mucoid on normal agar media; however, non-mucoid strains do occur $(2,3)$. Present methods being used for detection of the pathogen in tubers include immunofluorescence (IF; 6) and

Corresponding author: N. W. Schaad E-mail: schaad@ncifcrf.gov

This work was funded in part by a Cooperative Research and Development Agreement with Applied Biosystem Division of Perkin Elmer, Foster City, CA. TaqMan is a registered trademark of Roche Molecular Systems, Inc., Alameda, CA.

Present address of D. Knorr: Lynx Therapeutics, Hayward, CA 94545.

Accepted for publication 24 August 1999.

Publication no. D-1999-0928-01R

(C) 1999 The American Phytopathological Society enzyme-linked immunosorbent assay (ELISA; 8). The IF test has been part of the official European Community procedure for over 10 years (11). However, such serological methods generally require $>10,000 \mathrm{CFU} / \mathrm{ml}$ for a positive result and often suffer from problems due to low specificity (4). Recently, more sensitive PCR-based methods have been made available $(12,14,21,22)$. Firrao and Locci (12) and Slack et al. (22) reported a detection limit of 1 to $4 \times 10^{3} \mathrm{CFU} / \mathrm{ml}$ in pure cultures and Mills et al. (14) reported a sensitivity of $1 \times 10^{2} \mathrm{CFU} / \mathrm{ml}$ with spiked potato core fluid. Such sensitivity is a 10to 100-fold improvement over serological methods. However, the costs for polymerase chain reaction (PCR) become quite high when a Southern blot analysis is included to confirm identification of the PCR product. BIO-PCR (17) is 100-fold more sensitive than classical PCR but still requires a Southern blot analysis to confirm identity of the PCR product. With an appropriate medium, BIO-PCR is capable of detecting as few as $10 \mathrm{CFU} / \mathrm{ml}$ of test sample (19). Recently, an automated realwas developed that utilizes the $5^{\prime}$ to $>3^{\prime}$ exonuclease activity of $\mathrm{Taq}$ polymerase to remove a quenched fluorescent molecule from an oligonucleotide probe hybridized to a specific PCR target region (13). Our objective was to utilize BIO-PCR and the closed TaqMan lazer-based ABI Prism 7700 Sequence Detection System (Perkin time PCR-based assay system (TaqMan)
Elmer Applied Biosystems, Foster City, CA) to develop an improved molecularbased technique to detect the highly regulated C. michiganensis subsp. sepedonicus. An earlier version of the TaqMan technique using a luminescence spectrometer has been applied for detecting Escherichia coli in ground beef (23) and potato leafroll virus in potato tubers (20). We report for the first time the use of BIO-PCR and TaqMan 7700 Sequence Detection System for routine detection of a plant pathogen. We detected $C$. michiganensis subsp. sepedonicus in 18 of 22 field-grown symptomless potato tubers. A preliminary report of this research has been made (18).

\section{MATERIALS AND METHODS}

Growth of $C$. michiganensis subsp. sepedonicus on agar media. Based on preliminary tests of streaking several strains of $C$. michiganensis subsp. sepedonicus onto various media, NCP-88 medium (9) was chosen for selective growth of target cells from tuber extracts. To determine the time needed for cells of $C$. michiganensis subsp. sepedonicus to form pinpoint-sized (approximately $0.2 \mathrm{~mm}$ in diameter) colonies on NCP-88, an overnight liquid nutrient broth yeast extract (NBY; 18) culture of $C$. michiganensis subsp. sepedonicus strain Cms-4 was adjusted to 0.1 optical density (OD) at 600 $\mathrm{nm}$ and diluted 10 -fold serially to $10^{-7}$, and $100 \mu \mathrm{l}$ of the $10^{-5}, 10^{-6}$, and $10^{-7}$ dilutions were plated onto three plates each of NCP88 and NBY agar media. After 24, 48, and $72 \mathrm{~h}$ at $23^{\circ} \mathrm{C}$, one plate of each dilution was removed, observed under a dissecting microscope for colony development, and the size and total number of CFU recorded. Plates of the 24- and 48-h treatments were incubated for an additional $48 \mathrm{~h}$ to count the CFU.

Selection of primers and probes for TaqMan PCR. Primer and fluorescent probe sequences for the TaqMan PCR assay were designed with the Primer Design software program from the manufacturer (Perkin Elmer Applied Biosystems) using published sequences of $C$. michiganensis subsp. sepedonicus genomic DNA fragments designated $\mathrm{Cms} 50, \mathrm{Cms} 72$, and Cms 85 (14). Several combinations of forward $(\mathrm{F})$ and reverse $(\mathrm{R})$ primer and TaqMan probe $(\mathrm{T})$ sequences (Table 1) from C. michiganensis subsp. sepedonicus

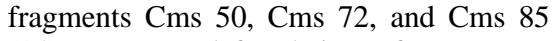
(14) were tested for their performance as 
determined by cycle threshold $(\mathrm{Ct})$ values. $\mathrm{Ct}$ value is defined as the PCR cycle number at which the signal (fluorescence) of the probe rises above background. The lower the $\mathrm{Ct}$ value, the better the PCR performance. TaqMan reactions were analyzed for 40 to 45 cycles using an $\mathrm{ABI}$ Prism 7700 Sequence Detection System following methods recommended by the manufacturer, including standard default PCR parameters. Cells of $C$. michiganensis cluded as positive and negative controls, respectively.

Specificity and sensitivity of primers. For specificity, 15 strains of $C$. michiganensis subsp. sepedonicus, 11 strains of four other subspecies, 7 other closely related Gram-positive bacteria, and 150 unknown bacteria isolated from potato tubers (Table 2) were grown on NBY for 1 to 3 days. A portion of the growth was transferred to a PCR tube using a sterile, wooden toothpick. The cells were suspended in $200 \mu \mathrm{l}$ of water and the zero and $10^{-1}$ dilution used for TaqMan PCR, as described above.

To determine inherent sensitivity and $\mathrm{Ct}$ values of TaqMan and Cms 50 primers, we did a titration curve using 1 to $100,000 \mathrm{pg}$ from four replicates of 5- and 10-fold dilutions of purified genomic DNA from strain P45 (gift of D. Mills, Oregon State University). Under the same PCR cycling conditions for classical and BIO-PCR, 10-fold serial dilutions to $10^{-6}$ of a liquid NBY culture of $C$. michiganensis subsp. sepesubsp. sepedonicus and water were in-

donicus strain Cms-4 were prepared. For classical TaqMan PCR, aliquots of $14 \mu \mathrm{l}$ of dilutions $10^{-3}, 10^{-4}, 10^{-5}$, and $10^{-6}$ were tested in duplicate. For BIO-PCR, aliquots of $100 \mu \mathrm{l}$ of the same dilutions were plated onto eight plates each of semiselective NCP-88 medium and NBY agar. After 72 $\mathrm{h}$, four plates were washed, as described below, and four kept for determining the number of CFU of $C$. michiganensis subsp. sepedonicus on NBY and NCP-88 agar media after 4 and 7 days, respectively.

Sampling and assay of tubers. A total of 30 dormant potato tubers suspected of being infected with $C$. michiganensis subsp. sepedonicus originating from Maine, Idaho, and Denmark and six healthy tubers from Maine were sampled (1) by the core tissue extraction shaker incubation procedure of Dinesen and DeBoer (11). All of the Idaho and Maine tubers were freshly harvested and appeared externally healthy. The older Denmark tubers had been cut in half and the vascular tissue had partially decayed. The tubers were considered suspect for ring rot. Cores (1.0 to $1.5 \mathrm{~cm}$ long) of individual tubers were removed using a No. 4 core borer $(0.9 \mathrm{~cm}$ diameter $)$, washed, and placed in $15-\mathrm{ml}$ centrifuge tubes with $5 \mathrm{ml}$ of distilled water. After 1 and $18 \mathrm{~h}$ at $23^{\circ} \mathrm{C}$ on a rocking shaker, samples of $1.0 \mathrm{ml}$ were removed, diluted 10 -fold serially to $10^{-2}$, and assayed immediately, as below, or stored on ice. The tubers were stored at $4^{\circ} \mathrm{C}$. Tuber extracts were assayed by (i) agar plating, (ii) classical TaqMan PCR,

Table 1. Comparison of primer/probe combinations used to detect three different genomic DNA fragments (Cms 50, Cms 72, and Cms 85$)$ of Clavibacter michiganensis subsp. sepedonicus by TaqMan polymerase chain reaction (PCR) and resulting fluorescence $(\Delta \mathrm{Rn})$ and cycle threshold $(\mathrm{Ct})$ values

\begin{tabular}{|c|c|c|c|c|c|}
\hline Sample & $\begin{array}{c}\text { Forward } \\
\text { primer }^{\mathrm{a}}\end{array}$ & $\begin{array}{l}\text { Reverse } \\
\text { primer }^{\text {a }}\end{array}$ & $\begin{array}{c}\text { TaqMan } \\
\text { probe }\end{array}$ & $\Delta \mathbf{R n}^{\mathbf{b}}$ & $\mathbf{C t}^{\mathfrak{c}}$ \\
\hline \multirow[t]{4}{*}{ Cms 50} & $50-2 \mathrm{~F}$ & $50-133 R$ & $50-53 \mathrm{~T}$ & 22.69 & 15.25 \\
\hline & & $50-\mathrm{R}^{*}$ & $50-53 \mathrm{~T}$ & 14.49 & 15.59 \\
\hline & $50 \mathrm{~F}^{*}$ & $50-133 R$ & $50-53 \mathrm{~T}$ & 24.35 & 15.91 \\
\hline & & $50-\mathrm{R}^{*}$ & $50-53 \mathrm{~T}$ & 15.69 & 15.53 \\
\hline \multirow[t]{4}{*}{ Cms 72} & $72-29 F$ & $72-169 R$ & $72-109 \mathrm{~T}$ & 1.07 & 18.73 \\
\hline & & $72 \mathrm{R}^{*}$ & $72-109 \mathrm{~T}$ & -0.02 & 40 \\
\hline & $72 \mathrm{~F}^{*}$ & $72-169 R$ & $72-109 \mathrm{~T}$ & 3.11 & 18.29 \\
\hline & & $72 \mathrm{R}^{*}$ & $72-109 \mathrm{~T}$ & 0.03 & 40 \\
\hline \multirow[t]{13}{*}{ Cms 85} & $85 \mathrm{~F}^{*}$ & $85-145 R$ & $85-66 \mathrm{~T}$ & 0.03 & 40 \\
\hline & & $85-182 \mathrm{R}$ & $85-66 \mathrm{~T}$ & 0.03 & 40 \\
\hline & & $85 R^{*}$ & $85-66 \mathrm{~T}$ & -0.03 & 40 \\
\hline & & $85-145 R$ & $85-126 \mathrm{~T}$ & 0.32 & 28.47 \\
\hline & & $85-182 R$ & $85-126 \mathrm{~T}$ & 1.07 & 29.97 \\
\hline & & $85 \mathrm{R}^{*}$ & $85-126 \mathrm{~T}$ & 0.48 & 28.17 \\
\hline & $85.21 \mathrm{~F}$ & $85-145 R$ & $85-66 \mathrm{~T}$ & -0.06 & 40 \\
\hline & & $85-182 R$ & $85-66 \mathrm{~T}$ & 0.33 & 34.67 \\
\hline & & $85 \mathrm{R}^{*}$ & $85-66 \mathrm{~T}$ & 0.33 & 34.99 \\
\hline & & $85-182 R$ & $85-126 \mathrm{~T}$ & 0.70 & 35.06 \\
\hline & & $85 \mathrm{R}^{*}$ & $85-126 \mathrm{~T}$ & 0.28 & 37.24 \\
\hline & $85-68 \mathrm{~F}$ & $85-182 \mathrm{R}$ & $85-126 \mathrm{~T}$ & 3.68 & 24.14 \\
\hline & & $85 \mathrm{R}^{*}$ & $85-126 \mathrm{~T}$ & 3.42 & 23.71 \\
\hline Buffer (3 reps) & $\ldots$ & $\ldots$ & $\ldots$ & 0.00 & $\ldots$ \\
\hline
\end{tabular}

a $*=$ Primer sequence given in Mills et al. (14).

${ }^{\mathrm{b}} \Delta \mathrm{Rn}$ is the amount of fluorescence liberated during the entire PCR (40 cycles). The higher the probe cleavage the better.

${ }^{c} \mathrm{Ct}$ value is defined as the PCR cycle number at which the signal of the probe rises above background. A lower value is better. and (iii) TaqMan BIO-PCR as described below.

For agar plating, $100 \mu \mathrm{l}$ of each undiluted and 10-fold dilution of tuber extract was plated onto each of five plates of NBY and semiselective medium NCP-88. After 5 to 7 days at $23^{\circ} \mathrm{C}$, suspect colonies were removed and cloned on NBY. Typical colonies were then identified by PCR and pathogenicity, using eggplant seedlings as described (5). For classical TaqMan PCR, 14- $\mu 1$ aliquots of each undiluted and 10fold dilution of tuber washings were assayed in duplicate by direct PCR. For TaqMan BIO-PCR, 100- $\mu$ l aliquots of the undiluted washings were plated onto each of five NCP-88 agar plates. After $72 \mathrm{~h}$, the resulting bacterial growth was collected by washing each plate three times using $1 \mathrm{ml}$ of distilled water. The plate washings (15 $\mathrm{ml}$ ) were pooled and $1 \mathrm{ml}$ diluted 10 -fold serially to $10^{-3}$. Aliquots of $14 \mu \mathrm{l}$ of each dilution were used in duplicate for PCR.

\section{RESULTS}

Growth of $C$. michiganensis subsp. sepedonicus on agar media. Colonies of C. michiganensis subsp. sepedonicus strain Cms-4 on NBY and NCP-88 media were easily visible under the dissecting microscope (10x) after 48 and $72 \mathrm{~h}$, respectively. On NCP-88 plates containing fewer than 20 colonies, a typical colony of $C$. michiganensis subsp. sepedonicus measured approximately 0.8 to $1.0 \mathrm{~mm}$ in diameter after $72 \mathrm{~h}$ at $23^{\circ} \mathrm{C}$. The mean number of CFU of $C$. michiganensis subsp. sepedonicus on NCP-88 and NBY were similar.

Specificity and sensitivity of primers. Forward primer (Cms 50-2F), (5')CGGAGCGCGATAGAAGAGGA; reverse primer (Cms 133R) (5')GGCAGAGCATCGCTCAGTACC; and TaqMan probe (5')AAGGAAGTCGTCGGATGAAGATGCG (Cms 50-53T) resulted in the lowest $\mathrm{Ct}$ values (15.25 to 15.91$)$ and were therefore chosen for further testing. All other primer probe combinations had much higher $\mathrm{Ct}$ values (Table 1). Results of screening these newly designed TaqMan primers against $C$. michiganensis subsp. sepedonicus and numerous other bacteria showed the primers to be specific based on the screens (Table 2). All strains of $C$. michiganensis subsp. sepedonicus, including non-mucoid strains 80452 and INM, were positive. All 150 unknown bacteria isolated from potato tubers were negative. The DNA titration results showed that fluorescence rose above background after 15 cycles for $100,000 \mathrm{pg}$ and after 32 cycles for $1 \mathrm{pg}$ (Table 3). Amplification of DNA from cells of C. michiganensis subsp. sepedonicus was typically positive after 20 to 30 cycles of amplification (Fig. 1). Suspensions of $C$. michiganensis subsp. sepedonicus containing around $200 \mathrm{CFU} / \mathrm{ml}$ were consistently positive by classical TaqMan PCR. Washings of plates of NBY and NCP-88 containing 1 to 2 colonies of 
C. michiganensis subsp. sepedonicus were consistently positive by TaqMan PCR.

Assay of tubers. Of the $30 \mathrm{C}$. michiganensis subsp. sepedonicus suspect tubers tested, 4 tubers were positive by agar plating on NCP-88, 8 by classical TaqMan PCR, and 26 by TaqMan BIO-PCR (Table 4). Of the 22 symptomless but C. michiganensis subsp. sepedonicus-suspect tubers, 18 were positive by BIO-PCR. No samples were positive by plating onto NBY agar medium due to overgrowth with other bacteria (Fig. 2A). Although some individual colonies could be observed on NCP-88 agar (Fig. 2B), suspect colonies of C. michiganensis subsp. sepedonicus were not easily recognized and few were retained from each source. Only four suspect colonies were confirmed to be positive by pathogenicity tests (Table 4). We observed no difference in results from $1 \mathrm{~h}$ and $18 \mathrm{~h}$ of incubation of the core tissue in distilled water. For the positive TaqMan controls, detectable amplification occurred at 20 cycles as above; whereas, in the tuber samples, detectable products were observed at or between 28 to 37 cycles (Fig. 3). No samples from the six healthy tubers or water were positive by any of the techniques.

\section{DISCUSSION}

Our results of designing primers within the Cms 50-DNA fragment agree with earlier results (14) that the fragment is unique for $C$. michiganensis subsp. sepedonicus. No other known or unknown bacteria we tested reacted with these primers. We found TaqMan to be very useful in choosing which sets of primers amplify best. Our TaqMan results showed that primers from the other fragments had higher $\mathrm{Ct}$ values, and reduced probe cleavage $(\Delta \mathrm{Rn})$ and were therefore not tested further. We detected $C$. michiganensis subsp. sepedonicus in each of the three sources of suspected tubers by both PCR techniques and by NCP-88 agar plating. Although our BIO-PCR results could not be confirmed by pathogenicity tests, each of the tubers positive by isolation and pathogenicity were positive by BIO-PCR. Several of the older ring rot-suspect tubers from Denmark showed symptoms (exudate) of infection and had partially decayed. The difficulty in detecting $C$. michiganensis subsp. sepedonicus by isolation (only 4 of 30 tubers) was due primarily to overgrowth by other bacteria. By 7 days, visual detection of $C$. michiganensis subsp. sepedonicus on NCP-88 was extremely difficult. A much-improved selective medium would be needed for direct isolation. In contrast, because the NCP-88 plates used for BIO-PCR only needed to be incubated for $72 \mathrm{~h}$ instead of 7 days, none of the plates with undiluted samples were completely overgrown with other bacteria. These results with tuber extracts confirm our earlier results with pure cultures that $72 \mathrm{~h}$ is enough time to produce pinpoint-size colonies on NCP-88 agar. Identification of $C$. michiganensis subsp. sepedonicus on NBY was even more difficult. Most plates were completely overgrown with other bacteria by 3 days. Our rather poor results with classical TaqMan PCR agree with earlier classical PCR results showing a minimum requirement of $1 \times 10^{3} \mathrm{CFU}$ of $C$. michiganensis subsp. sepedonicus to be positive (22). Slack et al. (22) found, in a comparison between classical PCR, ELISA, and DNA hybridization with tubers from inoculated plants, that PCR failed to increase sensitivity over ELISA. They reported a sample-detection sensitivity (number of samples positive) for classical PCR, ELISA, and DNA probe of $36.2,35.8$, and $29.1 \%$, respectively.

Our results with TaqMan BIO-PCR agree with the high sensitivity (2 to 3 cells $/ \mathrm{ml}$ ) of BIO-PCR with nested primers and Southern blot analysis for detecting the single copy Tox gene fragment in Pseudomonas syringae pv. phaseolicola (19).

Table 2. Source of strains and specificity of TaqMan primers to fragment Cms 50 of Clavibacter michiganensis subsp. sepedonicus.

\begin{tabular}{|c|c|c|}
\hline Species and strains & Source $^{\mathrm{a}}$ & Primers $^{b}$ \\
\hline \multicolumn{3}{|c|}{ C. michiganensis subsp. sepedonicus } \\
\hline CMS $1,3,4,8$ & 1, Idaho & + \\
\hline INM, AS-1, CMS-OFF & 2, Wisconsin & + \\
\hline AS-1, Wi-2, OFF-1, SD-1 & 3, North Dakota & + \\
\hline $80451-93,80452-93$ & 4, Pennsylvania & + \\
\hline $80453-93,80352-92$ & 4, Pennsylvania & + \\
\hline \multicolumn{3}{|c|}{ C. michiganensis subsp. nebraskensis } \\
\hline CN103, 104 & 5, Nebraska & - \\
\hline \multicolumn{3}{|c|}{ C. michiganensis subsp. insidiosus } \\
\hline CI-134 & 6, Wisconsin & - \\
\hline CI-113, 124 & 6, New York & - \\
\hline \multicolumn{3}{|c|}{ C. michiganensis subsp. michiganensis } \\
\hline CM 188B & 6, Australia & - \\
\hline CM 206 & 6, Hawaii & - \\
\hline CM 185 & 6, England & - \\
\hline CM 187 & 6, Unknown & - \\
\hline CM 184 & 6, Brazil & - \\
\hline \multicolumn{3}{|c|}{ C. michiganensis subsp. tesselarius } \\
\hline 78180 & 5, Nebraska & - \\
\hline \multicolumn{3}{|l|}{ C. iranicus } \\
\hline 2253 & 5, Nebraska & - \\
\hline \multicolumn{3}{|l|}{ C. tritici } \\
\hline 1857 & 5, Nebraska & - \\
\hline CT 106 & 6, Egypt & - \\
\hline \multicolumn{3}{|c|}{ Curtobacterium flaccumfaciens pv. pointsettiae } \\
\hline CP 21A & 6, Florida & - \\
\hline 13 & 5 , Nebraska & - \\
\hline \multicolumn{3}{|l|}{ C. flaccumfaciens pv. betae } \\
\hline $\mathrm{CB} 102,374$ & 5, Nebraska & - \\
\hline \multicolumn{3}{|c|}{ Unknown bacteria from potato tubers } \\
\hline 150 Total Strains & 7, Local market & - \\
\hline
\end{tabular}

a $1=$ W. Chun, University of Idaho, Moscow; $2=$ T. German, University of Wisconsin, Madison; $3=$ N. Gudmestad, North Dakota State University, Fargo; 4 = S. H. Kim, Pennsylvania Department of Agriculture, Harrisburg; 5 = A. Vidaver, University of Nebraska, Lincoln; $6=$ International Collection of Plant Pathogenic Bacteria, Ft. Detrick, MD; 7 = original.

${ }^{\mathrm{b}}+$ indicates fluorescence signal detected after 30 cycles or less and - indicates no fluorescence signal detected after 40 cycles.

Table 3. Titration data for TaqMan system using Cms 50 primers and probe ${ }^{\mathrm{a}}$

\begin{tabular}{lrll}
\hline Sample no. & DNA $(\mathbf{p g})$ & Ct Value & StDev \\
\hline 1 & 100,000 & 16.3 & 0.00 \\
2 & 50,000 & 17.2275 & 0.19 \\
3 & 10,000 & 20.0375 & 0.30 \\
4 & 5,000 & 20.6925 & 0.15 \\
5 & 1,000 & 22.98 & 0.19 \\
6 & 500 & 23.35 & 0.18 \\
7 & 100 & 26.2625 & 0.67 \\
8 & 50 & 26.95 & 0.48 \\
9 & 10 & 29.86 & 0.50 \\
10 & 5 & 30.58 & 0.19 \\
11 & 1 & 32.27 & 0.30 \\
12 & 0 & 40 & 0.00 \\
\hline
\end{tabular}

${ }^{a}$ Purified Clavibacter michiganensis subsp. sepedonicus genomic DNA (D. Mills, Oregon State University) was diluted serially and then four replicates of each sample were run using the same polymerase chain reaction cycling conditions. $\mathrm{Ct}$ value $=$ cycle threshold value. 
Such sensitivity is 100 - to 1,000 -fold greater than achieved with classical PCR. It is significant that even tubers in a state of decay can be found positive in our TaqMan BIO-PCR technique. We did observe that plate washings from undiluted potato core samples often failed to amplify. Only when such samples were diluted did amplification proceed normally, suggesting inhibition of PCR reactions at high cell densities. Further evidence of inhibition of PCR was suggested by the higher $\mathrm{Ct}$ values of tuber samples in comparison to samples of pure cultures of $C$. michiganensis subsp. sepedonicus. Inhibition of PCR by food (10) and plant samples $(15,16)$ has been observed and was one of the factors which led to the development of BIO-PCR (19).

Advantages of BIO-PCR over classical PCR include (i) ability to use a 10-fold greater volume of sample (100 versus 10 $\mu \mathrm{l})$ of the original tuber extract, (ii) a greater number of target cells resulting from the biological amplification, (iii) elimination of PCR inhibitors resulting from the tubers, and (iv) elimination of false positives due to dead cells. A disadvantage is the extra 2 days needed for the agar plating. However, by use of the 7700 real-time fluorescence detection system, a Southern blot analysis is not needed to confirm identification of the amplified product revealed by agarose gel electrophoresis. Because no agarose gel electrophoresis or Southern is needed, the technique requires only 1 day more than

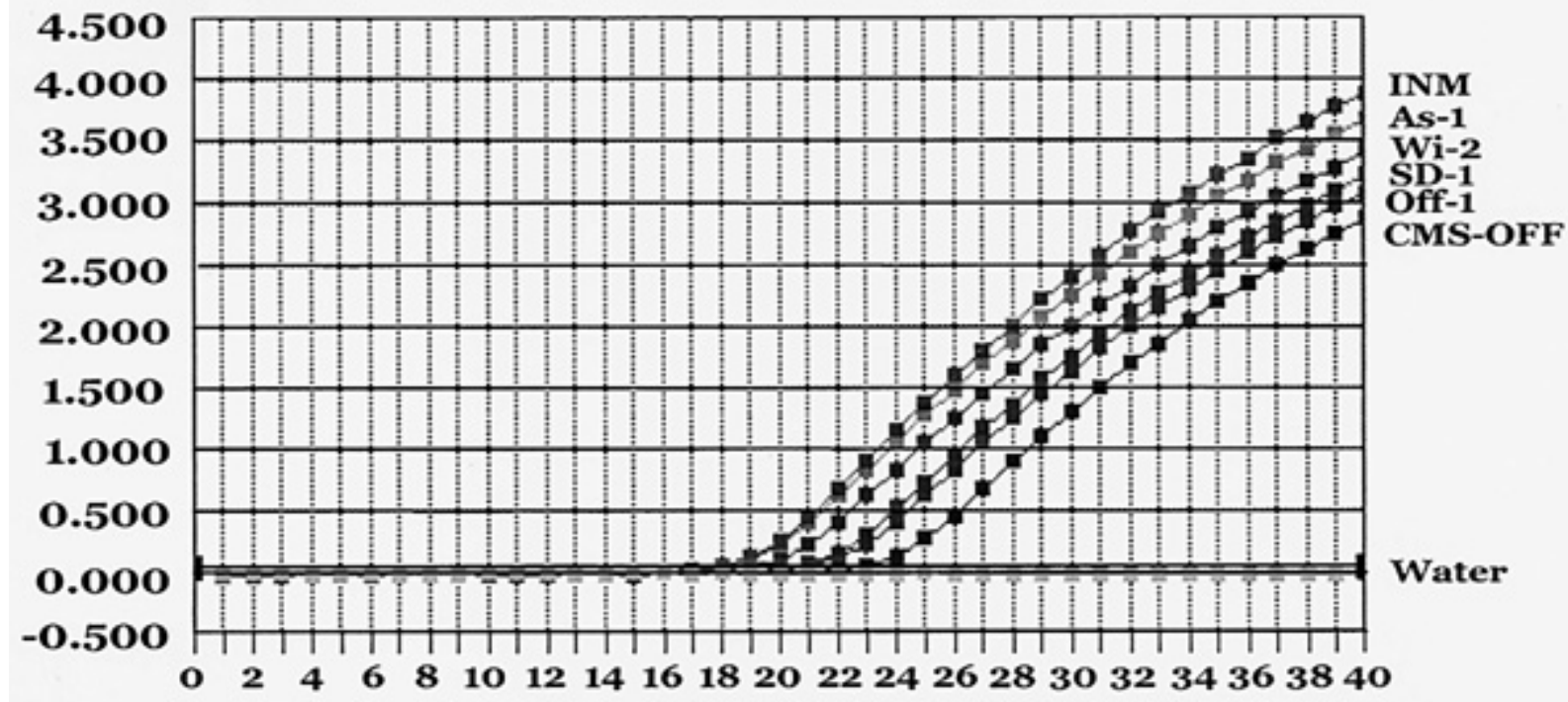

\section{Cycle}

Fig. 1. Amplification of DNA of eight known strains of Clavibacter michiganensis subsp. sepedonicus by TaqMan polymerase chain reaction (PCR) and an ABI Prism 7700 Sequence Detection System. A portion of the growth of each strain was transferred to a PCR tube just prior to PCR. Cycle thresholds (lowest to highest) are (17) INM, (18) AS-1, (19) Wi-2, (20) SD-1, (21) Off-1, (23) Clavibacter michiganensis subsp. sepedonicus-OFF, and water control. Left axis $(\triangle \mathrm{RQ})$ is the change in fluorescence which is a measure of probe cleavage efficiency.
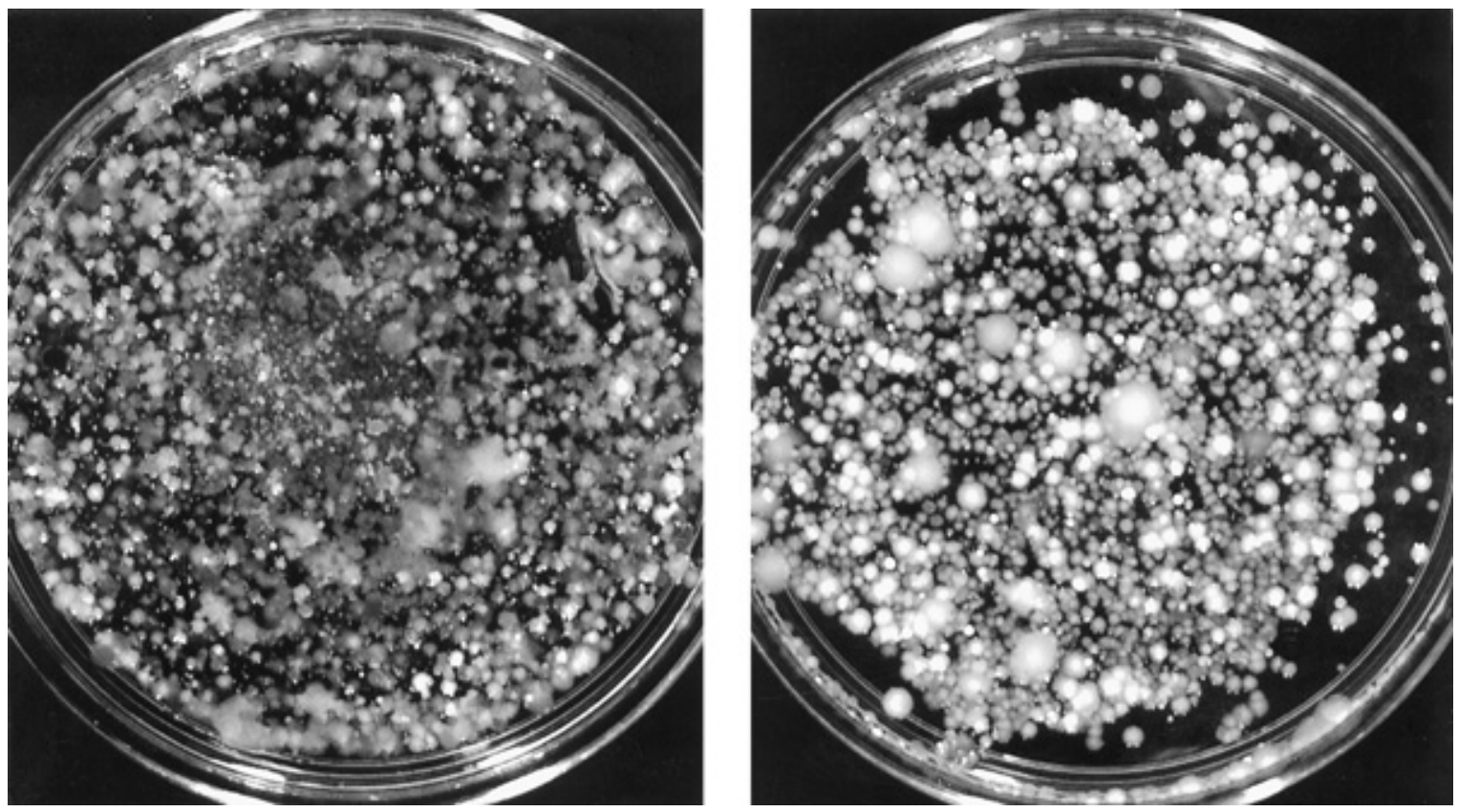

Fig. 2. Appearance of bacterial growth resulting from plating $100 \mu \mathrm{l}$ of a zero dilution of potato core extract onto (left) nutrient bro th yeast extract medium and (right) NCP-88 medium after 3 days at $23^{\circ} \mathrm{C}$. 
classical PCR to allow for biological amplifications. This considerably reduces the cost per sample of PCR. Presently, the cost of the 7700 Detection System (nearly $\$ 100,000)$ is far too high for a small diagnostic laboratory. However, for a large central laboratory, the much-reduced labor and supply costs of the TaqMan system make it more cost effective than classical PCR. With the appearance of lower-cost detection systems, TaqMan will become more useful for smaller laboratories. With a total assay time of only 3 days, the TaqMan BIO-PCR technique provides a highly sensitive, high-throughput assay. An earlier TaqMan assay system was found to improve detection of potato leafroll virus (20).

For even greater reliability in identifying C. michiganensis subsp. sepedonicus, two additional unique $C$. michiganensis subsp. sepedonicus DNA sequence regions identified by Mills et al. (14) could possibly be incorporated into our assay by improving the primer/probe performance. An improved semiselective medium might increase the detection of $C$. michiganensis subsp. sepedonicus in decayed tubers. When combined with BIO-PCR, TaqMan can be a highly sensitive and reliable routine technique of detecting pathogens often present in latent infections, such as $C$. michiganensis subsp. sepedonicus in potato tubers.

\section{ACKNOWLEDGMENTS}

We thank R. Goth, S. H. Kim, and I. G. Dinesen for supplying potato tubers; D. Mills for genomic DNA for the titration experiment; and S. Slack for kindly reviewing the manuscript.

\section{LITERATURE CITED}

1. Anonymous. 1987. Scheme for the detection and diagnosis of the ring rot bacterium Cory-

Table 4. Detection of Clavibacter michiganensis subsp. sepedonicus in naturally infected suspect potato tubers by isolation, classical TaqMan, and TaqMan BIO-polymerase chain reaction (PCR) using 7700 Detection System ${ }^{\mathrm{a}}$

\begin{tabular}{lcccc}
\hline & & \multicolumn{3}{c}{ Number of positive tubers } \\
\cline { 4 - 5 } Tuber source & No. of tubers & NCP-88 $^{\mathbf{b}}$ & Classical PCR $^{\mathbf{c}}$ & BIO-PCR $^{\mathbf{d}}$ \\
\hline Denmark & 8 & 1 & 2 & 8 \\
Idaho & 3 & 1 & 2 & 2 \\
Maine & 19 & 2 & 4 & 16 \\
Totals & 30 & 4 & 8 & 26 \\
\hline
\end{tabular}

${ }^{a}$ A number 4 cork borer $(0.9 \mathrm{~cm}$ in diameter $)$ was used to remove a sample of tissue $(1.0$ to $1.5 \mathrm{~cm}$ long) from each tuber. The cores were incubated in $5 \mathrm{ml}$ of sterile distilled water on a shaker for $1 \mathrm{~h}$ at $23^{\circ} \mathrm{C}$. Samples of $1.0 \mathrm{ml}$ were removed, diluted serially to $10^{-2}$, and each undiluted and 10 -fold dilution assayed, as above. Plates for Bio-PCR were washed after $72 \mathrm{~h}$ at $23^{\circ} \mathrm{C}$.

${ }^{\mathrm{b}}$ Isolation on NCP-88 agar. Numbers of tubers positive, based on pathogenicity tests.

${ }^{c}$ Classical PCR and TaqMan. Fluorescence signal detected after 40 cycles or less.

d BIO-PCR and TaqMan. Fluorescence signal detected after 40 cycles or less. nebacterium sepedonicum in batches of potato tubers. Rep. Eur. 11288. Office Off. Publ. Eur. Communities, Luxembourg.

2. Baer, D., and Gudmestad, N. C. 1993. Serological detection of nonmucoid strains of Clavibacter michiganensis subsp. sepedonicus in potato. Phytopathology 83:157-163.

3. Bishop, A., Clarke, R., and Slack, S. 1988. Antigenic anomaly in a naturally occurring nonfluidal strain of Corynebacterium sepedonicum. Potato J. 65:237-246.

4. Crowley, C. F., and DeBoer, S. H. 1982 Nonpathogenic bacteria associated with potato stems cross-react with Corynebacterium sepedonicum antisera in immunofluorescence. Am. Potato J. 59:1-8.

5. DeBoer, S. H. 1987. The relationship between bacterial ringrot and North American seed potato export markets. Am. Potato J. 64:683-693.

6. DeBoer, S. H., Copeman, R. J. 1980. Bacterial ring rot testing with indirect fluorescent antibody staining procedure. Am. Potato J 57:457-465.

7. DeBoer, S. H., and Slack, S. A. 1984. Current status and prospects for detecting and controlling bacterial ring rot of potatoes in North America. Plant Dis. 68:841-844.

8. DeBoer, S. H., Wieczorek, A., and Kummer, A. 1988. An ELISA test for bacterial ring rot of potato with a new monoclonal antibody. Plant Dis. 72:874-878.

9. de la Cruz, A. R., Wiese, M. V., and Schaad, N. W. 1992. A semiselective agar medium for isolation of Clavibacter michiganensis subsp. sepedonicus from potato tissues. Plant Dis. 76:830-834.

10. Demeke, T., and Adams, R. P. 1992. The effects of plant polysaccharides and buffer additives of PCR. BioTechniques 12:332-334.

11. Dinesen, I. G., and DeBoer, S. H. 1995. Extraction of Clavibacter michiganensis subsp. sepedonicus from composite samples of potato tubers. Am. Potato J. 72:133-142.

12. Firrao, G., and Locci, R. 1994. Identification of Clavibacter michiganensis subsp. sepedonicus using the polymerase chain reaction. Can. J. Microbiol. 40:148-151.

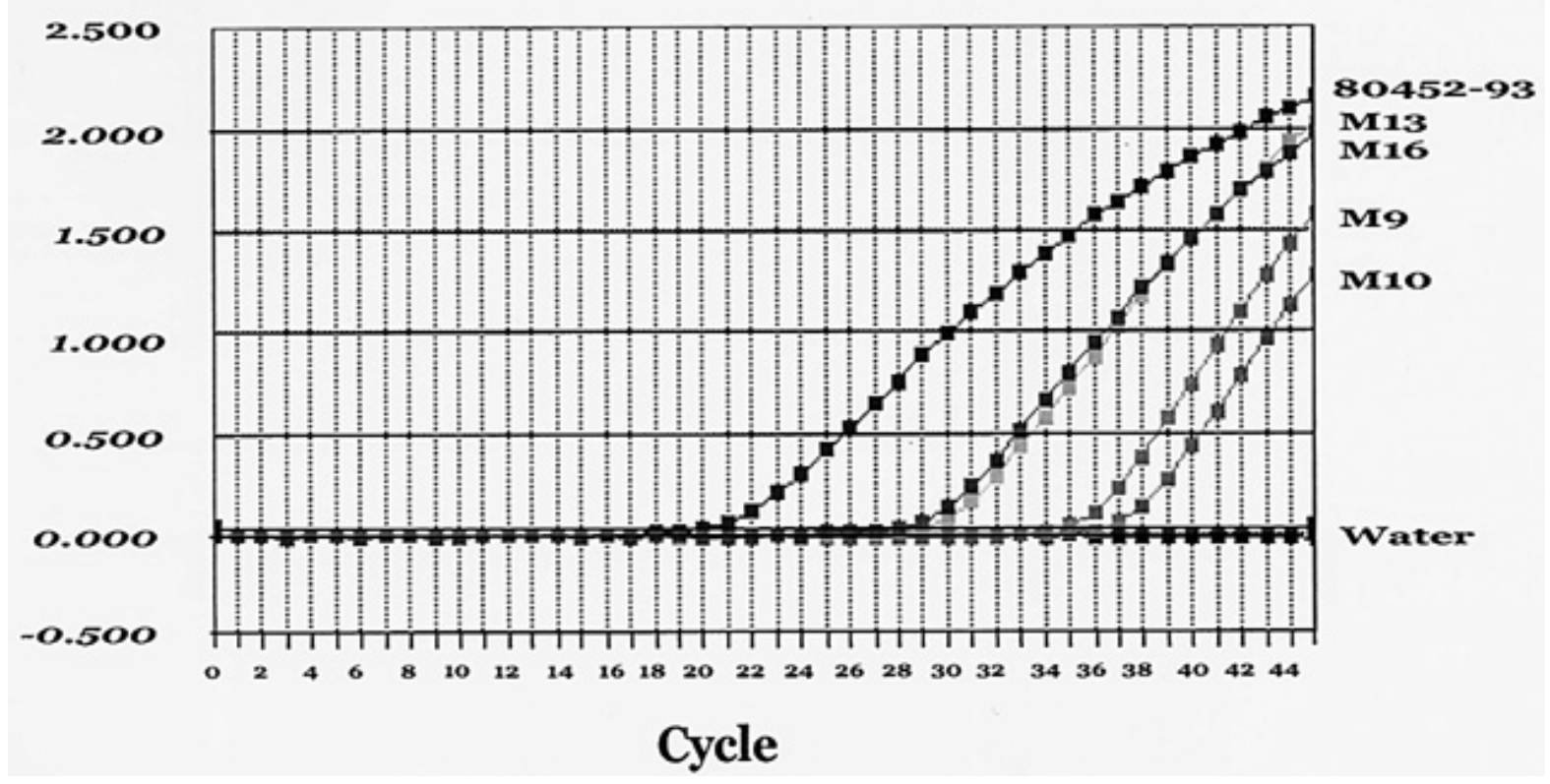

Fig. 3. Typical results of TaqMan BIO-polymerase chain reaction (PCR) assays of core extracts of four potato tubers (M-9, M-10, M-13, and M-16) from Maine naturally infected with Clavibacter michiganensis subsp. sepedonicus. Left axis $(\Delta \mathrm{RQ})$ is the change in fluorescence which is a measure of probe cleavage efficiency. An aliquot of $100 \mu \mathrm{l}$ of extract was plated onto each of five NCP-88 agar plates. After $72 \mathrm{~h}$ at $23^{\circ} \mathrm{C}$, each plate was washed three times with $1 \mathrm{ml}$ of water and pooled into a $15-\mathrm{ml}$ sample. After diluting 10 -fold, two $15-\mu l$ aliquots were used in duplicate PCR reactions. The controls and extract samples and cycle threshold (Ct) values (lowest to highest) are (20) C. michiganensis subsp. sepedonicus 80452-93 (positive control), (28) M-16, (29) M-13, (35) M-9, (36) M-10, and (baseline) water control. Left axis ( $\triangle \mathrm{RQ}$ ) is the amount of fluorescence liberated during the entire PCR (40 cycles) and is a measure of cleavage efficiency. 
13. Livak, K. J., Flood, S. J. A., Marmaro, J., Giusti, W., and Deetz, K.. 1995. Oligonucleotides with fluorescent dyes at opposite ends provide a quenched probe system useful for detecting PCR product and nucleic acid hybridization. PCR Methods Appl. 4:357-362.

14. Mills, D., Russell, B. W., and Hanus, J. W. 1997. Specific detection of Clavibacter michiganensis subsp. sepedonicus by amplification of thee unique DNA sequences isolated by subtraction hybridization. Phytopathology 87:853-861.

15. Prosen, D., Hatziloukas, E., Schaad, N. W., and Panopoulos, N. J. 1993. Specific detection of Pseudomonas syringae pv. phaseolicola DNA bean seed by polymerase chain reaction-based amplification of a phaseolotoxin gene region. Phytopathology 83:965-970.

16. Rossen, L., Norskov, P., Holmstrom, K., and Rasmussen, O. F. 1992. Inhibition of PCR by components of food samples, microbial diagnostic assays and DNA-extraction solutions. Int. J. Food Microbiol. 17:37-45.

17. Schaad, N. W. 1988. Initial identification of common genera. In: Laboratory Guide for Identification of Plant Pathogenic Bacteria. APS Press, St. Paul, MN.

18. Schaad, N. W., Berthier-Schaad, Y., Sechler, A., and Knorr, D. 1998. Use of BIO-PCR and an automated fluorescence detection system for reliable detection of Clavibacter michiganensis subsp. sepedonicus in potato tubers. (Abstr.) Int. Congr. Plant Pathol. Edinburgh, Scotland.

19. Schaad, N. W., Cheong, S. S., Tamaki, S., Hatziloukas, E., and Panopoulos, N. J. 1995. A combined biological amplification (BIOPCR) technique to detect Pseudomonas syringae pv. phaseolicola in bean seed extracts. Phytopathology 85:243-248.
20. Schoen, C. D., Knorr, D., and Leone, G. 1996. Detection of potato leafroll virus in dormant potato tubers by immuno capture and a fluorogenic 5' nuclease RT-PCR assay. 1996. Phytopathology 86:993-999.

21. Schneider, J., Zhao, J., and Orser, C. S. 1993 Detection of Clavibacter michiganensis subsp. sepedonicus by DNA amplification. FEMS Microbiol. Lett. 109:207-212.

22. Slack, S. A., Drennan, J. L., Westra, A. A. G., Gudmestad, N. C., and Oleson, A. E. 1996. Comparison of PCR, ELISA, and DNA hybridization or the detection of Clavibacter michiganensis subsp. sepedonicus in fieldgrown potatoes. Plant Dis. 80:519-524.

23. Witham, P. K., Yamashiro, C. T., Livek, K. J., and Batt, C. A. 1996. A PCR-based assay for the detection of Escherichia coli Shiga-like toxin genes in ground beef. Appl. Environ. Microbiol. 62:1347-1353. 